Article

\title{
Varieties Matter When Planning for Poverty Alleviation and Ecological Restoration in Karst Fruit Cultivation Areas
}

\author{
Zhigang Zou ${ }^{1,2,3}$, Fuping Zeng ${ }^{1,3}$, Kelin Wang ${ }^{1,3} \mathbb{D}$, Zhaoxia Zeng ${ }^{1,3}$ and Hao Zhang ${ }^{1,3, *}$ \\ 1 Key Laboratory of Agro-Ecological Processes in Subtropical Region, Institute of Subtropical Agriculture, \\ Chinese Academy of Sciences, Changsha 410125, China; zhigangzou0203@163.com (Z.Z.); \\ fpzeng@isa.ac.cn (F.Z.); kelin@isa.ac.cn (K.W.); zengzhx@isa.ac.cn (Z.Z.) \\ 2 College of Resource and Environment, University of Chinese Academy of Sciences, Beijing 100049, China \\ 3 Huanjiang Observation and Research Station for Karst Ecosystem, Chinese Academy of Sciences, \\ Huanjiang 547100, China \\ * Correspondence: zhanghao@isa.ac.cn; Tel.: +86-186-8497-6587
}

Citation: Zou, Z.; Zeng, F.; Wang, K.; Zeng, Z.; Zhang, H. Varieties Matter When Planning for Poverty Alleviation and Ecological Restoration in Karst Fruit Cultivation Areas. Sustainability 2021, 13, 12211. https://doi.org/10.3390/su132112211

Academic Editors:

Raúl Romero-Calcerrada, Javier Cabello,

Manuel Pacheco-Romero and Koldo Trapaga Monchet

Received: 6 October 2021

Accepted: 2 November 2021

Published: 5 November 2021

Publisher's Note: MDPI stays neutral with regard to jurisdictional claims in published maps and institutional affiliations.

Copyright: (c) 2021 by the authors. Licensee MDPI, Basel, Switzerland. This article is an open access article distributed under the terms and conditions of the Creative Commons Attribution (CC BY) license (https:/ / creativecommons.org/licenses/by/ $4.0 /)$.

\begin{abstract}
Landscapes are increasingly being managed to meet multiple objectives and balance social, economic, and environmental goals. The Honghe Hani and Yi Autonomous Prefecture in the Yunnan faulted Basin represent examples of areas with a range of concerns, including balancing farming with poverty alleviation, economic development, and ecological protection. Here, we set out four future land-use scenarios to quantify and map the values of key evidence-based, policy-relevant ecosystem services in three typical counties in this area. We found that implementing existing fruitgrowing plans may increase the expected total value of ecosystem services due to increased acreage, but it does not actually increase the total value of ecosystem services per unit area. For example, total ecosystem service provision in Jianshui County decreased by 3\% by 2023 under the current trend after the expansion of the planting area was subtracted. However, planting fruit trees with better ecological benefits in areas of greater degradation risk, can increase the delivery of ecosystem services by $10-20 \%$. Thus, variety coordination based on detailed study of the geographical contexts and ecological-economic performance of different types of fruit cultivation can produce ecologicaleconomic improvements beyond simple expansion and better inform county-scale policy, planning, and management interventions.
\end{abstract}

Keywords: scenario analysis; karst; Yunnan; fruit; land-use

\section{Introduction}

The faulted Yunnan Basin is a major rocky desertified area in China formed by violent unbalanced crustal movements during the Tertiary period [1,2]. The annual erosion modulus of soil can reach $98,100 \mathrm{t} / \mathrm{km}^{2} \cdot \mathrm{a}$, which is much higher than the average $500 \mathrm{t} / \mathrm{km}^{2} \cdot \mathrm{a}$ for much of China [3,4]. These unique geographical conditions lead to a simple community structure that is vulnerable to degradation under human disturbance, which in turn leads to excessive population growth and economic poverty [5]. The population density of most karst counties in Yunnan Province is much higher than in other provinces, generally 120-250 people $/ \mathrm{km}^{2}$ [6]. By 2017, there were 2.79 million poor people in Yunnan, accounting for $9.1 \%$ of China's poorest population. These areas often consist of undeveloped barren hillsides suitable for fruit cultivation. In addition, fruit trees provide ecological functions, including soil and water conservation, which can help promote the development of ecological tourism, leisure tourism, and other industries $[7,8]$.

Given these opportunities, China's central and local governments issued a series of documents to support the development of fruit farming and eliminate rural poverty; these include "some opinions on giving priority to the development of agriculture and rural areas and doing a good job in the work of agriculture, rural areas, and farmers" and the "targeted poverty alleviation plan of Yunnan Province's Characteristic Industries" 
(http: / / www.gov.cn; http:/ / www.yn.gov.cn/, accessed on 30 September 2020). Between 2008 and 2018, the annual average fruit planting area and output of Yunnan displayed rapid and stable growth at $7.6 \%$ and $9.9 \%$, respectively (http:/ / data.stats.gov.cn, accessed on 30 September 2020), with "one main producing area and four sub-areas" becoming the main production area along with Honghe Prefecture [9]. The per capita net income of rural residents in karst areas also increased by $79.9 \%$, which was higher than the national mean of $54.4 \%$ for the same period [10].

Numerous studies have been conducted on the overall impacts of industrial poverty alleviation and various ecological projects (e.g., afforestation and grass planting; forest and grassland protection) [11-13]. However, those efforts focused mainly on long-term trends or macro-scale processes using remote sensing images and models, while less attention has been paid to specific modes of planting at the town scale [12-15]. Furthermore, existing studies have demonstrated that different varieties of fruit have different economic and ecological values [16-18], which makes it possible to improve the total output of regional ecosystem services through the coordinated cultivation of multiple varieties of fruit. However, to the best of our knowledge, there have not been many studies on this. To address this knowledge gap, this study used scenario-based simulation and a geographical information system (GIS) framework to explore changes in ecosystem service delivery associated with the development of fruit planting in Yunnan Province, and the transformational effects of different production modes at the county scale. In doing so, we explored the impacts of the coordinated planting of fruit varieties on regional-scale economic and ecological benefits.

\section{Materials and Methods}

\subsection{Research Area and Fruit Production Modes}

Honghe Hani and Yi Autonomous Prefecture, Yunnan Province, China, is a typical faulted karst basin where $17.58 \%$ of the population $(587,000$ people) live below the poverty line and $45.04 \%\left(2345.08 \mathrm{~km}^{2}\right)$ of the country is undergoing desertification [19]. In the last 20 years, the fruit-growing industry has begun to develop in this area with the support of government poverty alleviation policies and the implementation of a three-phase desertification control project.

This study focused on three typical demonstration areas subject to desertification in Honghe Hani and Yi Autonomous Prefecture: Jianshui County, Luxi County, and Mengzi City (Figure 1). Based on the Statistical Yearbook (2015-2018) and a 2016 preliminary field survey, two typical planting modes were selected for each site (Table A2). Orange and pomegranate cultivation were selected for Jianshui County, which has an elevation ranging from $230-2515 \mathrm{~m}$, average annual temperature of $19.4^{\circ} \mathrm{C}$, average annual rainfall of $1045.5 \mathrm{~mm}$, and an annual average of $2047.9 \mathrm{~h}$ of sunshine. Pear and peach cultivation were selected for Luxi County, which has an elevation ranging from 820-2459 m, average annual temperature of $16.0{ }^{\circ} \mathrm{C}$, average annual rainfall of $1028.1 \mathrm{~mm}$, and an annual average of $1951.1 \mathrm{~h}$ of sunshine. Finally, apple and marigold cultivation were selected for Mengzi City, which has an elevation ranging from $397-2494 \mathrm{~m}$, average annual temperature of $19.0^{\circ} \mathrm{C}$, annual average rainfall of $1377.1 \mathrm{~mm}$, and an annual average of $2228.3 \mathrm{~h}$ of sunshine (Table A1). To obtain the data required, a face-to-face questionnaire survey was conducted with farmers from July-September in 2017 and 2018, and field samples were collected in 2017 and tested in 2018 [20].

\subsection{Geospatial Data}

Slope data was calculated from a $30 \mathrm{~m} \times 30 \mathrm{~m}$ resolution digital elevation model (DEM) obtained from the Geoscientific Data Cloud website (http:/ / www.gscloud.cn, accessed on 30 September 2020). Land-use data for 2015, at the same resolution, were derived from Landsat-8 images [21]. Monthly temperature and rainfall data were obtained from the National Meteorological Data Center and interpolated from 2012-2016 records. 


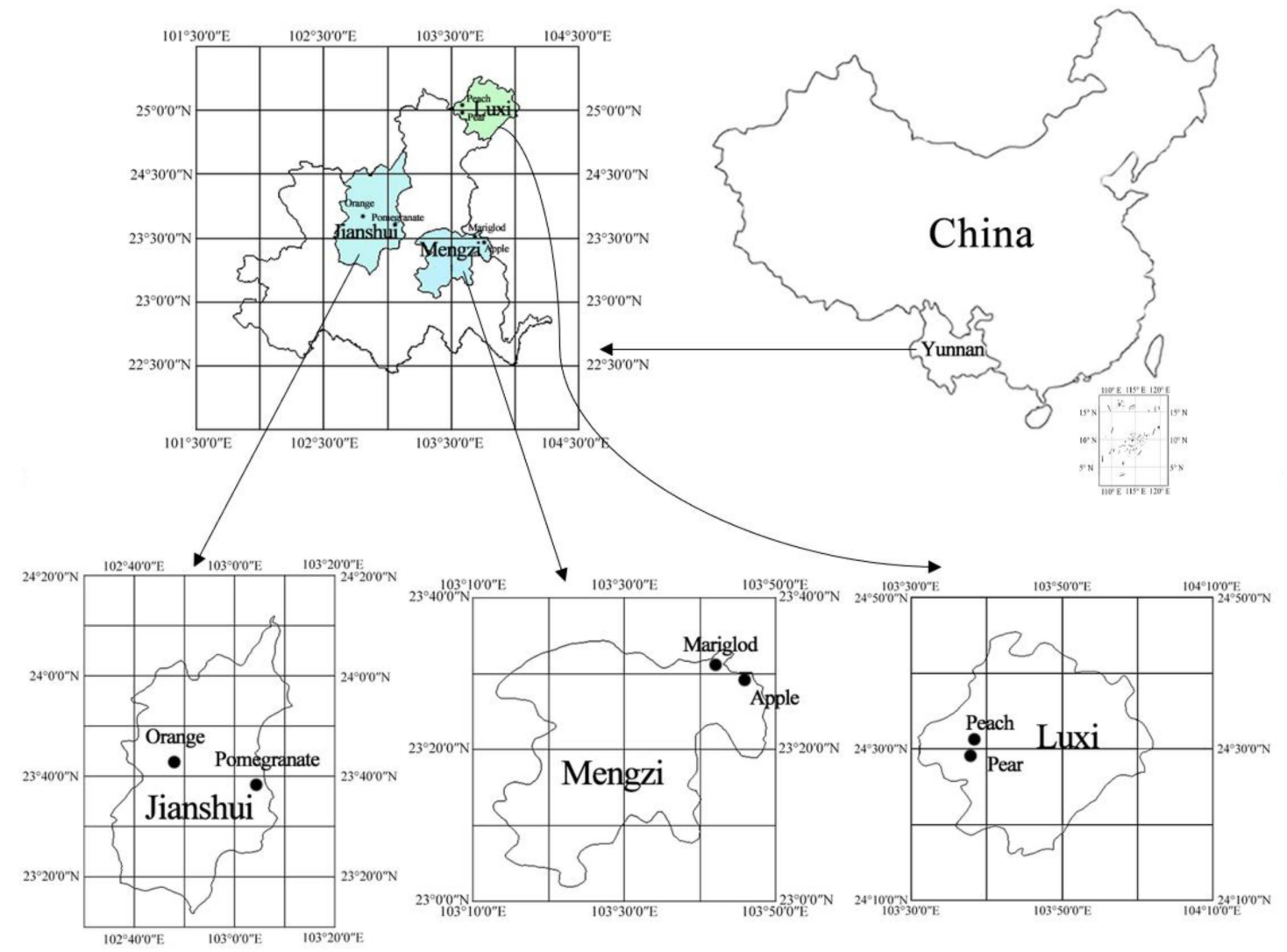

Figure 1. Locations of the research areas in Yunnan Province and the cultivation modes selected.

To evaluate the maximum area suitable for planting in each mode, climatic and geographical factors were classified, as follows. The "Technical Regulations for Investigation of Land Use Status" and "Technical Regulations for Determining the Gradation of Cultivated Land Using DEM (for trial implementation)" guidelines were used to divide slope gradients into the following four grades: $\left\langle 6^{\circ}, 6-15^{\circ}, 15-25^{\circ}\right.$, and $>25^{\circ}$. The growth characteristics of the modes of cultivation studied were used to divide the annual average rainfall into the following categories: $<750 \mathrm{~mm}, 750-1000 \mathrm{~mm}, 1000-1250 \mathrm{~mm}$, and $>1250 \mathrm{~mm}$. The annual average temperature was divided into the following categories: $<15^{\circ} \mathrm{C}, 15-20^{\circ} \mathrm{C}$, and $>20^{\circ} \mathrm{C}$. We aimed to focus on the economic and ecological benefits brought about by changes in planting modes; hence, land-use data were reclassified into eight categories including rice fields, other farmland, bare farmland, and forests. All GIS layers were generated as $30 \mathrm{~m} \times 30 \mathrm{~m}$ raster images.

\subsection{Ecosystem Service Data}

Previous studies have found that climate factors and altitude can significantly change the ripening time of fruits planted in Yunnan, but have little effect on other characteristics [22]. Therefore, we used pattern-based ecosystem service data from previous studies to represent the entire study area (Table A4). Briefly, we categorized the provision of fruits and flowers into the following ecosystem services as per the Millennium Ecosystem Assessment framework and evaluation criteria for karst regions: general provisioning services, reducing topsoil loss, maintaining soil fertility, and photosynthetic carbon fixation as a regulating service, photosynthetic oxygen release and nutrient retention as supporting services, and education as a cultural service [20] (Tables A3 and A4). In general, pomegranate cultivation should be prioritized where economic benefits are sought and apple cultivation should be promoted where ecological benefits are needed. 
To eliminate the impact of the differences in the composition of and calculation methods for different ecosystem services, relative ecosystem services were calculated based on the following formulas.

$$
\text { Relative } E S=\frac{E S_{i}-E S_{i-\min }}{E S_{i-\max }-E S_{i-\min }}
$$

In Equation (1), Relative ES is the value of one specific type of ecosystem service (ES) after standardization, $E S_{i}$ represents the actual total amount of ecosystem service $i$ (e.g., maintaining soil fertility) in one quadrat, $E S_{i-\max }$ is the maximum value of the actual total amount of ecosystem service $i$ in all land-use patterns quadrats, and $E S_{i-\min }$ denotes the minimum value under the same condition.

To equalize the weights of the contributions of the four types of ecosystem services to total ecosystem services (TES), the latter was calculated using Equation (2). The modified index eliminated the impact of differences in the number of types of service in each category.

$$
\mathrm{TES}=\frac{\sum_{i=1}^{n}{\text { Relative } E S_{P}}_{P}}{n}+\frac{\sum_{j=1}^{m} \text { Relative } E S_{R}}{m}+\frac{\sum_{j=1}^{f}{\text { Relative } E S_{S}}_{f}}{f}+\frac{\sum_{j=1}^{t} \text { Relative } E S_{C}}{t}
$$

In Equation (2), Relative $E S_{p}$ is the standardized value of provisioning services.

\subsection{Scenario Setting}

Planting area data for each planting mode in 2016, 2017, and 2018 were obtained from the three county governments. The planting areas for each mode in 2023 were used as the baseline scenario (i.e., the result of development according to current trends). In the ecological priority scenario, the planting mode with the greatest ecological benefits is promoted preferentially; in the economic priority scenario, the planting mode with the greatest economic benefits is promoted. A land classification map of the three counties was obtained at the same time to help identify areas suitable for planting and those at high risk of degradation; this was done by superposing topography, soil erosion, land-use, and climate datasets (Figure 2, Tables A5-A7). The scenario analysis was conducted based on the transformation of farmland into various planting modes, as per the relevant national land-use policies and regulations (e.g., Law of the People's Republic of China on Land Administration; Forest Law of the People's Republic of China), and is summarized in Table 1.

Table 1. Principles used to design cultivation scenarios for the study region (Zou et al., 2019).

\begin{tabular}{ll}
\hline Scenarios & Description \\
\hline \multirow{2}{*}{ Baseline scenario } & Existing policies and regulations are not adjusted. \\
& $\begin{array}{l}\text { No major technological advances occur for any of the planting modes. } \\
\text { Planting structure strongly promotes higher economic output. All new planting areas and suitable } \\
\text { areas obtained from reducing areas planted in other modes are planted with crops with high } \\
\text { Economic priority scenario }\end{array}$ \\
& $\begin{array}{l}\text { Planting structure is transformed to high modes of economic output while limiting ecological } \\
\text { damage. Crops with high economic value are planted in areas where the risk of erosion is low. }\end{array}$ \\
Compromise scenario & $\begin{array}{l}\text { Areas where the risk of erosion is high are planted with crops of high ecological value. } \\
\text { Planting structure strongly promotes high ecological gains. All new planting areas and suitable } \\
\text { areas obtained from reducing areas planted in other modes are planted with crops with high } \\
\text { ecological service value. }\end{array}$ \\
\hline
\end{tabular}

To better measure the changes in ecosystem services resulting from land-use changes, the equal-area change rate (EACR) was calculated based on Equation (3) as follows:

$$
\mathrm{EACR}=\frac{E S_{a-2023}-E S_{a-2018}}{E S_{a-2018}} * \frac{\text { Area }_{2018}}{\text { Area }_{2023}}
$$




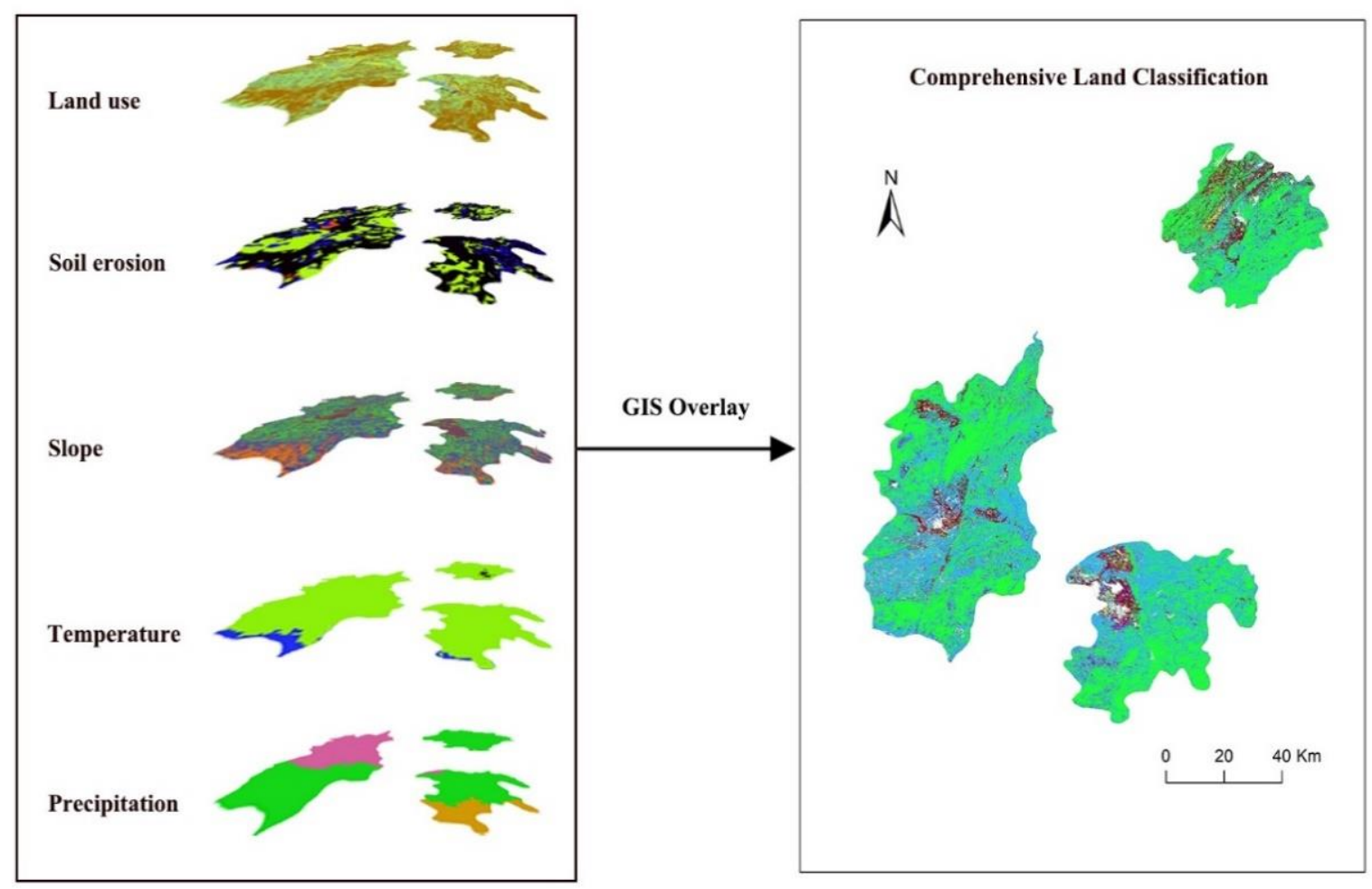

Figure 2. Geographical information system overlay process.

\section{Results}

3.1. Temperature, Rainfall, Slope, Soil Erosion, and Land-Use Patterns

Overall, 39.12\% of the study area had a slope gradient between 6 and $15^{\circ}, 24.28 \%$ had a gradient $<6^{\circ}$, and $24.64 \%$ ranged from $15^{\circ}$ and $25^{\circ}$. Steep areas $\left(>25^{\circ}\right)$ accounted for $11.96 \%$ of the total area of the three counties, although there was some variability between them. The terrain in Luxi County was relatively flat, with $6^{\circ}$ and $6-15^{\circ}$ slopes accounting for $74.73 \%$ of its land area and slopes $>25^{\circ}$ covering only $7.92 \%$ of the county. Slopes $<6^{\circ}$, $6-15^{\circ}$, and $15-25^{\circ}$ accounted for $21.25 \%, 38.90 \%$, and $26.50 \%$, respectively, of Jianshui County; steeper slopes $\left(>25^{\circ}\right)$ accounted for $13.36 \%$ and were located mainly in the central region. Slope gradient distribution in Mengzi City was similar to that in Jianshui County, with $<6^{\circ}$ slopes accounting for $24.57 \%$ of the land area, $6-15^{\circ}$ slopes accounting for $35.91 \%$, $15-25^{\circ}$ slopes accounting for $26.95 \%$, and $>25^{\circ}$ slopes accounting $12.57 \%$, the last mainly in the northwest (Figure 3c).

Most soil erosion across the entire study area was classified as 'slight' (59.11\%) or 'mild' $(29.05 \%)$. The area of 'moderate' erosion accounted for $10.99 \%$ of the total, whereas only $0.58 \%$ of the land was classified as experiencing 'intense' erosion. In Luxi County, areas of 'slight' and 'mild' erosion accounted for $89.94 \%$ of the land area, with the remaining areas experiencing 'moderate' erosion (11.47\%). In Jianshui County, erosion levels in $98.32 \%$ of the land was classified as either 'slight' (52.17\%), 'mild' (34.83\%), or 'moderate' (11.32\%), with $1.68 \%$, mainly in the central area, undergoing 'intense' erosion. In Mengzi City, 73.75\% of the land was classified as experiencing 'mild' erosion; combined with areas of 'slight' and 'moderate' erosion, this accounted for $99.97 \%$ of the total. Areas of 'moderate' erosion were concentrated mainly in the central-eastern area of the city (Figure $3 \mathrm{~d}$ ).

The land-use types in the study area were mainly grassland (48.79\%) and shrubland $(35.77 \%)$; forests only accounted for $1.70 \%$ (Figure 4 ). All farmland types accounted for $7.49 \%$ of the total area. The proportion of grassland in Luxi County was greater than the overall average at $55.72 \%$ and were mainly distributed in the east and south. Shrubland accounted for $23.66 \%$; some scattered forests accounted for $1.69 \%$; and farmland, which was concentrated mainly in the northwestern and central regions, accounted for 13.57\%. 
Grassland (46.97\%), shrubland (39.57\%), and forests (16.74\%) accounted for the majority of the land area in Jianshui County. Farmland in this area was mainly concentrated in its northwest and central regions and accounted for $5.69 \%$ of its land area; this was lower than the overall average for the study area. Similarly, grassland, shrubland, and forests accounted for $46.75 \%, 38.46 \%$, and $1.75 \%$ of the area in Mengzi City. Farmland accounted for $5.78 \%$ of its area and was concentrated mainly in its northwestern corner (Figure 4).
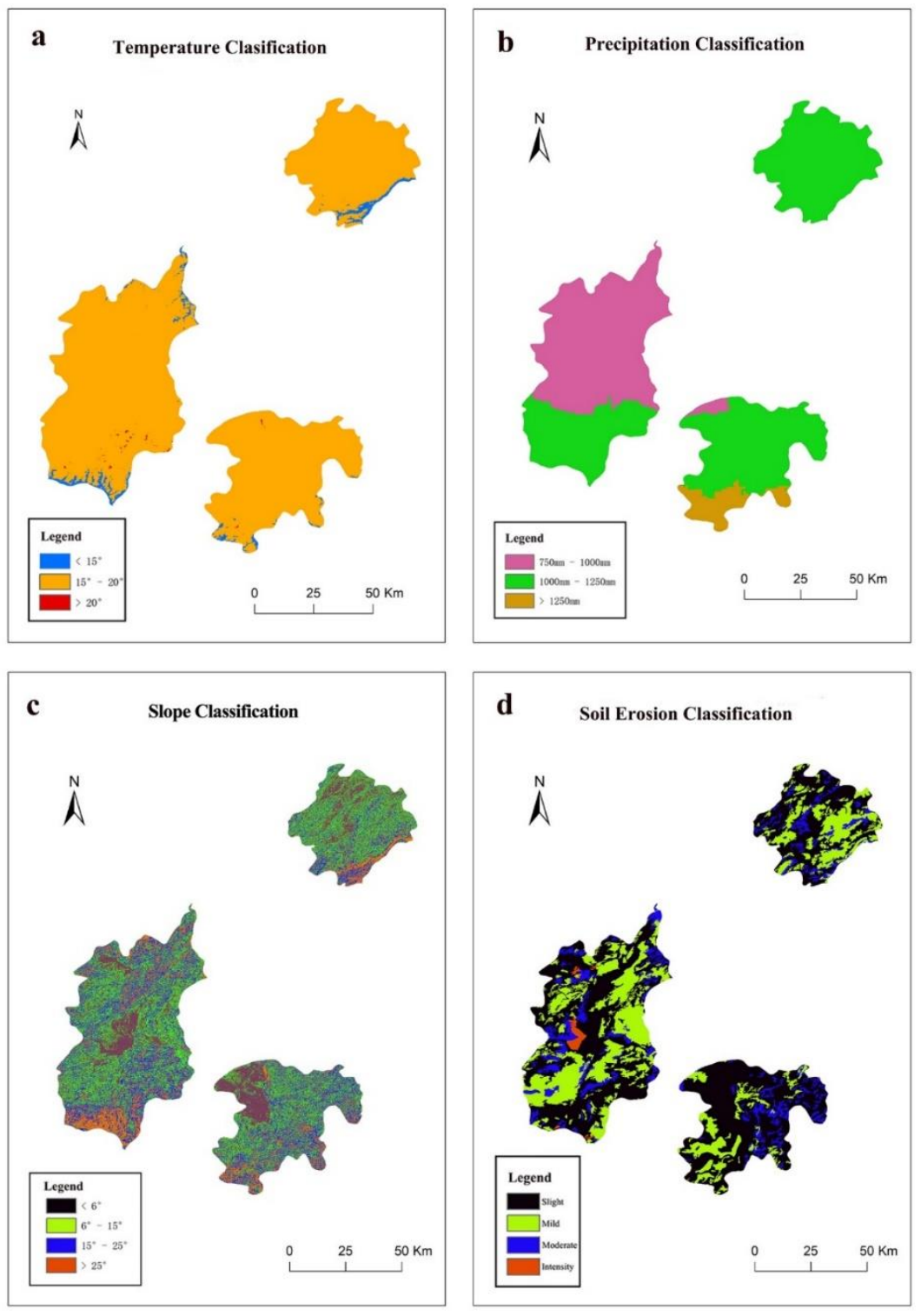

Figure 3. Classifications of (a) temperature, (b) precipitation, (c) slope, and (d) soil erosion in the study area.

A comparison of the rainfall and temperature classifications with the growth characteristics of each cultivation mode demonstrates that each of the counties could support the planting of all six fruit species considered; this is consistent with the field survey. Overall, land in Luxi County was divided into 14 categories (Table A5), of which land with a slope $<6^{\circ}$, 'slight' erosion, a mean annual temperature of $15-20{ }^{\circ} \mathrm{C}$, and mean annual rainfall of 1000-1250 mm accounted for the largest area. The same was found for Mengzi City, although this was divided into 15 different categories (Table A7). Land in Jianshui County was more variable, and was thus classified into 37 different categories (Table A6). Here, areas with a slope $<6^{\circ}$, 'slight' erosion, mean annual temperature of $15-20{ }^{\circ} \mathrm{C}$, and mean annual rainfall of $750-1000 \mathrm{~mm}$ accounted for the largest area. Finally, land at high 
risk of erosion in Luxi County accounted for 2300.58 ha compared to 4698.9 ha in Jianshui County and 489.23 ha in Mengzi City (Tables A5-A7).

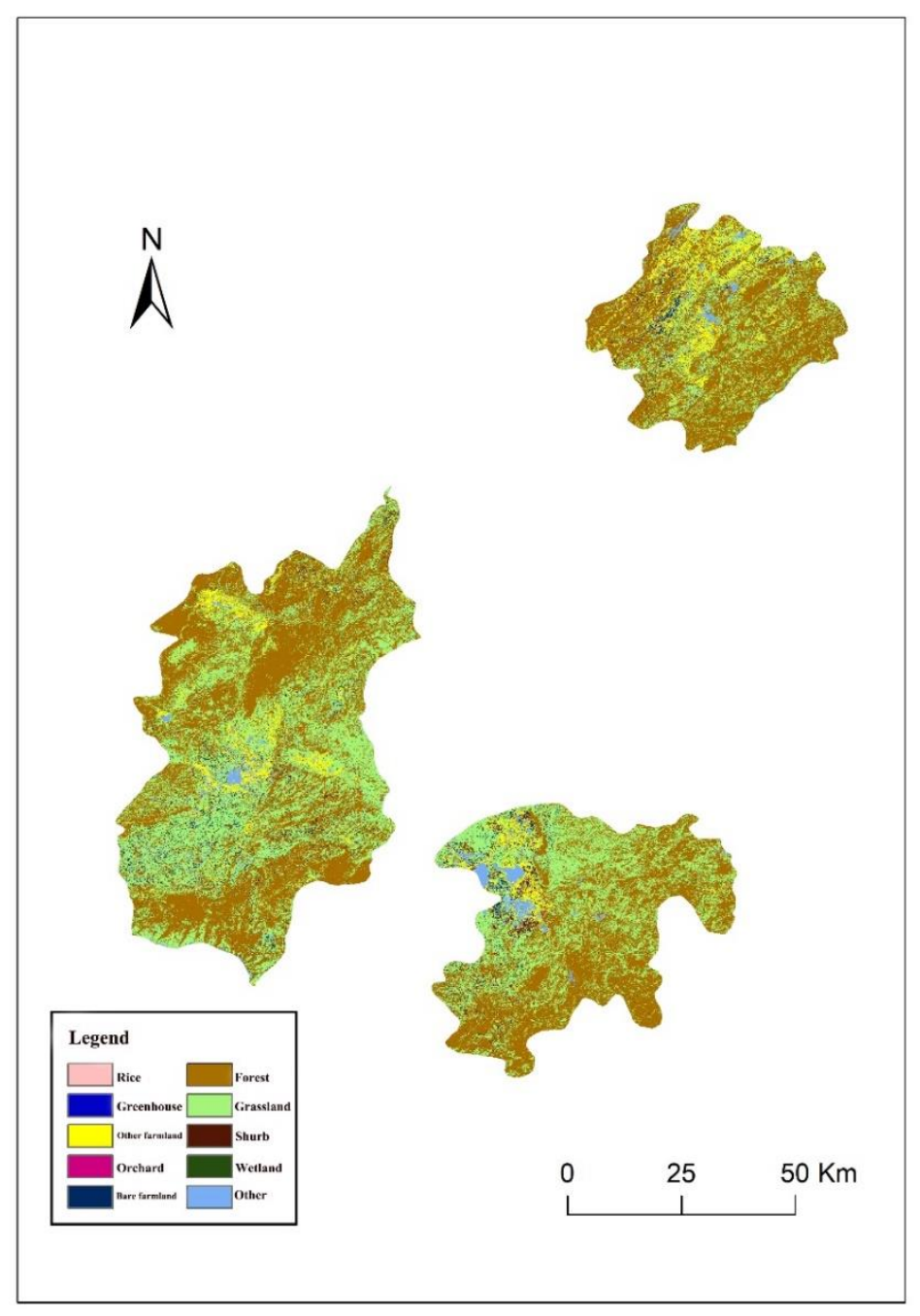

Figure 4. Classification of land uses in the study area.

\subsection{Change in Planting Area under Different Scenarios}

According to the statistics for 2016-2018 obtained from the Luxi County government, the marigold planting area decreased by $31 \%$ each year; based on this trend, the estimated planting area would be 87.03 ha by 2023. The apple planting area, calculated using the same principles but with a positive trend, is expected to reach 5094.02 ha by 2023 . Across all crop types considered, an additional 7374.98 ha of land is expected to be newly planted by 2023 compared to 2018 (Table 2). In terms of the different scenarios, pomegranate cultivation was promoted in the economic priority scenario, increasing in planting area by 7854.62 ha. Under the compromise scenario, apples would be planted on 2300.58 ha of land at high risk of erosion and pomegranates would be planted in other areas. In the ecological priority scenario, all new growing areas would be planted with apple trees.

In Jianshu County, the pear planting area decreased between 2016 and 2018 at an average rate of $4 \%$ each year, with a projected 2023 planting area of 523.44 ha (Table 3). The planting areas for oranges, peaches, and pomegranates increased, with the orange cultivation area projected to increase the most to reach $10,764.80$ ha by 2023 . In general, compared to 2018, a total of 6736.38 ha is projected to be newly planted by 2023 (Table 3). Under the different scenarios, pomegranates account for $100 \%$ of this increase, whereas pear cultivation would be reduced by 128.89 ha. In the compromise scenario, 4698.9 ha 
of land at high risk of erosion would be planted with apples (for ecological gain) while the remaining areas are planted with pomegranates (for economic gain). In the ecological priority scenario, apple cultivation is prioritized in 6685.27 ha (Table 3).

Table 2. Changes in planting area (ha) of different crops in Luxi County under different scenarios.

\begin{tabular}{cccccccc}
\hline Luxi & Marigold & Orange & Pear & Peach & Apple & Pomegranate & Total Area \\
\hline 2016 & 1200.00 & 0.00 & 8860.00 & 3696.67 & 1066.67 & 0.00 & $14,823.33$ \\
2017 & 800.00 & 0.00 & 9193.33 & 3963.33 & 1366.67 & 0.00 & $15,323.33$ \\
2018 & 566.67 & 0.00 & 9593.33 & 4380.00 & 1666.67 & 0.00 & $16,206.67$ \\
Rate of change & -0.31 & & 0.04 & 0.09 & 0.25 & & \\
2023 & 87.03 & 0.00 & $11,703.55$ & 6697.04 & 5094.02 & 0.00 & $23,581.65$ \\
Economic priority & 87.03 & 0.00 & 9593.33 & 4380.00 & 1666.67 & 7854.62 & $23,581.65$ \\
Compromise & 87.03 & 0.00 & 9593.33 & 4380.00 & 3967.25 & 5554.04 & $23,581.65$ \\
Ecological priority & 87.03 & 0.00 & 9593.33 & 4380.00 & 9521.29 & 0.00 & $23,581.65$ \\
\hline
\end{tabular}

Table 3. Changes in planting area (ha) of different crops in Jianshui County under different scenarios.

\begin{tabular}{cccccccc}
\hline Jianshui & Marigold & Orange & Pear & Peach & Apple & Pomegranate & Total Area \\
\hline 2016 & 0.00 & 3536.73 & 712.53 & 523.93 & 0.00 & 1168.27 & 5941.47 \\
2017 & 0.00 & 3897.53 & 691.87 & 508.00 & 0.00 & 1414.93 & 6512.33 \\
2018 & 0.00 & 4848.20 & 652.33 & 542.47 & 0.00 & 1408.93 & 7451.93 \\
Rate of change & & 0.17 & -0.04 & 0.02 & & 0.10 & 0.12 \\
2023 & 0.00 & $10,764.80$ & 523.44 & 595.17 & 0.00 & 2304.90 & $14,188.31$ \\
Economic priority & 0.00 & 4848.20 & 523.44 & 542.47 & 0.00 & 8274.20 & $14,188.31$ \\
Compromise & 0.00 & 4848.20 & 523.44 & 542.47 & 4698.90 & 3575.30 & $14,188.31$ \\
Ecological priority & 0.00 & 4848.20 & 523.44 & 542.47 & 6865.27 & 1408.93 & $14,188.31$ \\
\hline
\end{tabular}

In Mengzi City, the marigold and apple planting areas greatly decreased between 2016 and 2018 at average annual rates of $17 \%$ and 13\%, respectively. Based on these trends, the marigold and apple planting areas are projected to be 402.26 ha and 1876.52 ha, respectively, by 2023. The pear planting area also slightly decreased during this period, whereas the peach planting area increased the most and is projected to reach $12,688.14$ ha by 2023 . Across all crop types, an area of $13,852.24$ ha is projected to be newly planted by 2023, compared to 2018. Pomegranate planting was included in all areas in Mengzi City under the economic priority scenario, with reductions in marigold, pear, and apple planting areas, totaling 14,480.94 ha. In the compromise scenario, 489.33 ha of land at high risk of erosion is planted with apples and the remaining 13,911.65 ha is planted with pomegranates. In the ecological priority scenario, the areas made available from reductions in marigold, pear, and apple cultivation are replanted with apple trees (Table 4).

Table 4. Changes in the planting area (ha) for different crops in Mengzi City under different scenarios.

\begin{tabular}{cccccccc}
\hline Mengzi City & Marigold & Orange & Pear & Peach & Apple & Pomegranate & Total Area \\
\hline 2016 & 1502.67 & 396.27 & 667.20 & 593.27 & 5001.40 & 4874.00 & $13,034.80$ \\
2017 & 1225.67 & 410.20 & 660.53 & 1469.53 & 5159.53 & 4742.87 & $13,668.33$ \\
2018 & 1031.00 & 686.20 & 649.20 & 1670.87 & 3690.73 & 5682.13 & $13,410.13$ \\
Rate of change & -0.17 & 0.35 & -0.01 & 0.50 & -0.13 & 0.09 & 8566.31 \\
2023 & 402.26 & 3122.82 & 606.32 & $12,688.14$ & 1876.52 & $27,262.37$ \\
Economic priority & 402.26 & 686.20 & 649.20 & 1670.87 & 3690.73 & $20,163.11$ & $27,262.37$ \\
Compromise & 402.26 & 686.20 & 649.20 & 1670.87 & 4180.06 & $19,673.78$ & $27,262.37$ \\
Ecological priority & 402.26 & 686.20 & 649.20 & 1670.87 & $18,171.71$ & 5682.13 & $27,262.37$ \\
\hline
\end{tabular}




\subsection{Changes in Ecosystem Service Provision}

According to the current development trends in Luxi County, the provisioning services provided by the six cultivation modes are expected to increase by 2023 at a rate of $4 \%$ (Figure 5a). The most significant increase is projected to be in regulating services, with an increase of $7 \%$, followed by supporting services at $6 \%$. Overall, TES in Luxi County is projected to increase by $6 \%$ by 2023 . Under the economic priority scenario, provisioning services in Luxi County increase by $246 \%$ by 2023 , compared to 2018. Supporting services and cultural services also increase by $2 \%$ and $10 \%$, respectively. However, regulating services are projected to decrease by $7 \%$ by 2023 . An overall increase of $15 \%$ in total ecosystem service provision is projected under the economic priority scenario. Under the compromise scenario, the increase in provisioning services is reduced and the EACR is $179 \%$; however, the reduction in regulating services also decreased, with an EACR of $-2 \%$, whereas there was a doubling of growth in supporting services. Overall, there was an approximate $14 \%$ increase in the growth rate of TES provision, which is in line with the economic priority scenario. In the ecological priority scenario, the EACR of the provisioning service is $17 \%$. However, the growth rate of regulating services and supporting services increased, with EACRs of $11 \%$ and $9 \%$, respectively. Overall, total ecosystem service provision increased by $11 \%$ under this scenario (Table 5).

Table 5. Equal-area change rate of ecosystem service provision in Luxi County, Jianshui County, Mengzi City, and the overall study area by 2023, under each scenario.

\begin{tabular}{ccccccc}
\hline Site & Scenario & Provisioning Regulating & Supporting & Cultural & TES \\
\hline \multirow{5}{*}{ Luxi } & 2023 & 0.04 & 0.07 & 0.06 & 0.04 & 0.06 \\
& Economic & 2.46 & -0.07 & 0.02 & 0.10 & 0.15 \\
& Compromise & 1.79 & -0.02 & 0.04 & 0.10 & 0.14 \\
& Ecological & 0.17 & 0.11 & 0.09 & 0.10 & 0.11 \\
\hline \multirow{5}{*}{ Jianshui } & 2023 & -0.15 & -0.01 & -0.04 & -0.01 & -0.03 \\
& Economic & 1.69 & -0.07 & 0.11 & 0.13 & 0.23 \\
& Compromise & 0.47 & 0.13 & 0.19 & 0.13 & 0.18 \\
& Ecological & -0.10 & 0.23 & 0.23 & 0.13 & 0.16 \\
\hline \multirow{5}{*}{ Mengzi } & 2023 & -0.28 & 0.11 & 0.08 & -0.08 & -0.03 \\
& Economic & 0.58 & -0.10 & 0.02 & 0.06 & 0.10 \\
& Compromise & 0.55 & -0.08 & 0.02 & 0.06 & 0.10 \\
& Ecological & -0.32 & 0.21 & 0.12 & 0.06 & 0.04 \\
\hline \multirow{5}{*}{ Overall } & 2023 & 0.50 & 0.87 & 0.84 & 0.73 & 0.78 \\
& Economic & 2.87 & 0.61 & 0.82 & 0.93 & 1.03 \\
& Compromise & 2.26 & 0.72 & 0.86 & 0.93 & 1.00 \\
& Ecological & 0.50 & 1.05 & 0.98 & 0.93 & 0.93 \\
\hline
\end{tabular}

Jianshui County, like Luxi County, is projected to experience an increase in the total provision of ecosystem services by 2023, based on current trends (Figure 5b). However, after excluding the change caused by the increase in the planting area, several ecosystem services are projected to decrease, with supporting services displaying the greatest decline of $-15 \%$. The EACR of supporting services is $4 \%$, and the declines in regulating and cultural services are both $1 \%$; the overall decline across all service types is $3 \%$. In the economic priority scenario, the growth rate of provisioning services is significant, with an EACR of $169 \%$. Supporting services and cultural services also display significant growth at $11 \%$ and $13 \%$, respectively. In contrast, regulating services display a $7 \%$ decline, resulting in an overall decrease of $23 \%$. Under the compromise scenario, all ecosystem services demonstrated significant increases; the rate of increase of provisioning services was the highest, with an EACR of $47 \%$. Supporting services also increased significantly, by $19 \%$, and the growth rates of both regulating and cultural services was $13 \%$. Overall, under the compromise scenario, total ecosystem service delivery is projected to increase by $18 \%$ by 2023 , which is much higher than the $3 \%$ reduction expected under the current trend. 
Finally, under the ecological priority scenario, regulating and supporting services increase to $23 \%$ while provisioning services are reduced by $10 \%$, although this is lower than the $15 \%$ decline expected under current trends. Overall, total ecosystem service delivery increases by $16 \%$ under this scenario (Table 5 ).
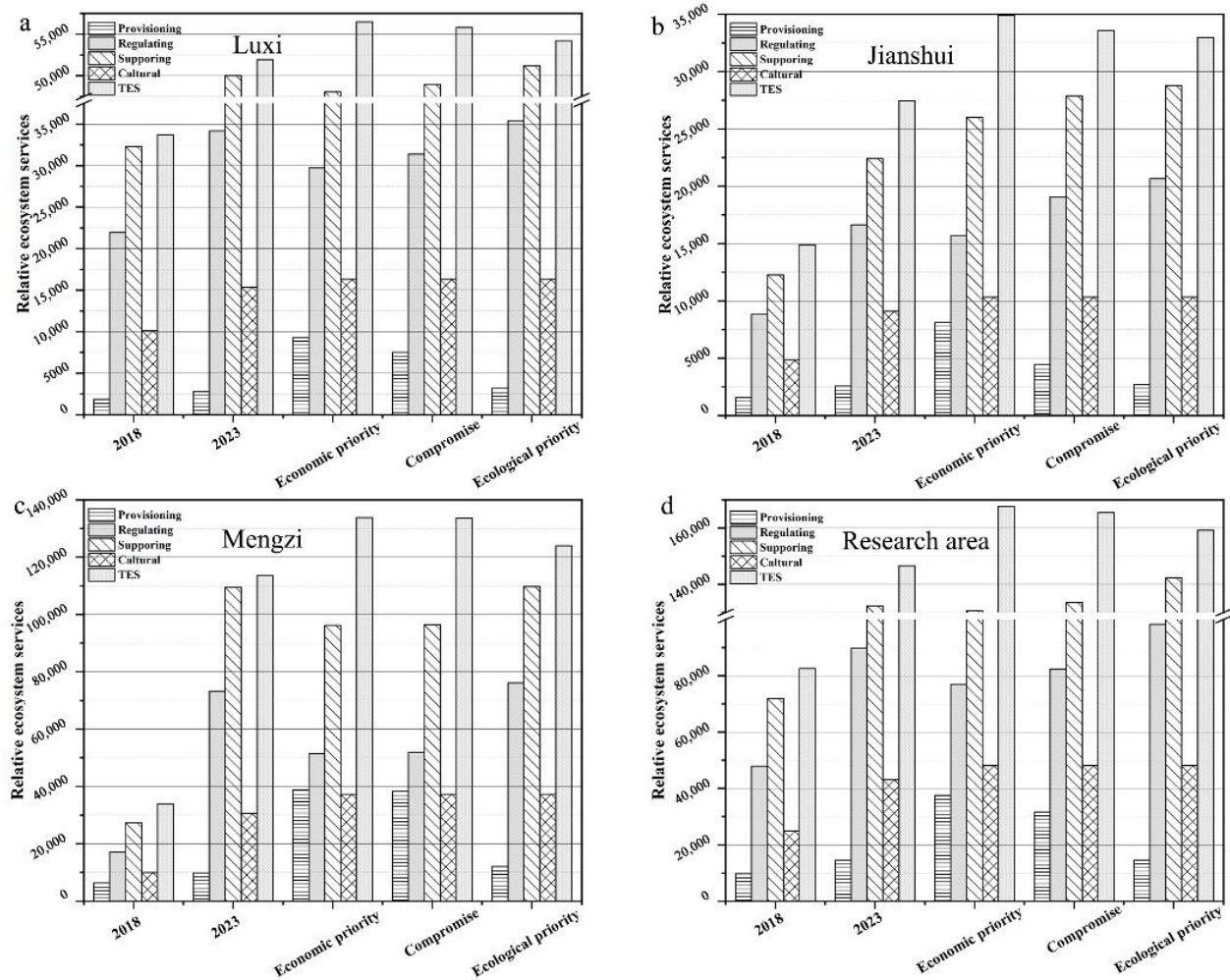

Figure 5. Ecosystem service provision under baseline (2018) and future (2023) conditions and five different scenarios for: (a) Luxi County, (b) Jianshui County, (c) Mengzi City, and (d) the overall research area. TES, total ecosystem services.

According to the trend for 2016-2018, various ecosystem services in Mengzi City are also projected to increase by 2023 (Figure 5c). Excluding the area factor, provisioning services displayed a notable downward trend at a $28 \%$ reduction; cultural services demonstrated a decline of $8 \%$. At the same time, regulating services and supporting services displayed significant growth rates of $11 \%$ and $8 \%$, respectively. As a result, a slight decline of $3 \%$ is projected overall. In the economic priority scenario, the growth of provisioning services is significant, with an EACR of $58 \%$. There are also slight increases, of $2 \%$ and $6 \%$, respectively, in supporting and cultural services. However, regulating services decrease by $10 \%$, resulting in overall growth of $10 \%$. In the compromise scenario, the increase in provisioning services decreases slightly to 55\%. The decline in regulating services is also slightly reduced at $8 \%$. Overall, there are no notable differences under the economic priority scenario, which has an EACR of $10 \%$. In the ecological priority scenario, there is a significant decline in provisioning services (by 32\%), whereas regulating and supporting services increase by $21 \%$ and $12 \%$, respectively, yielding an overall increase of $4 \%$ under this scenario (Table 5). 
Considering all areas together, all ecosystem service types are expected to increase by 2023 (Figure 5d), with an overall increase of 78\% accounting for area effects. Provisioning services increase the least at $50 \%$, while regulating and supporting services increase by $87 \%$ and $84 \%$, respectively. In the economic priority scenario, provisioning services have a significant increase at $287 \%$, supporting and cultural services increase by $82 \%$ and $93 \%$, respectively, and regulating services increase by $61 \%$. This equates to an overall increase in ecosystem services provision of $103 \%$. In the compromise scenario, the increase in provisioning is slightly dampened at $226 \%$, and regulating and supporting services display rates of change of $72 \%$ and $86 \%$, respectively. Overall, ecosystem service provision is slightly reduced relative to the economic priority scenario with an EACR of $100 \%$. In the ecological priority scenario, the change in provisioning services is consistent with the current trend at 50\%; however, growth in regulating and supporting services is significantly enhanced at $105 \%$ and $98 \%$, respectively. This equates to an overall increase in ecosystem services provision of $93 \%$ for this scenario (Table 5).

\section{Discussion}

The complex relationships between land-use and ecosystem services make it difficult for stakeholders to obtain and interpret key information on ecosystem service provision in different future land-use planning contexts [23]. Many studies have noted that land-use largely determines the transformation of regional ecosystem services, while the increase or decrease of ecosystem services will simultaneously cause changes in land-use modes [24,25]. In reality, the mutual transformation of different land-use modes is often accompanied by the expansion of specific land-use types. Unlike previous studies that have focused on multi-category land-use types (e.g., grassland, forests, and farming areas) $[26,27]$, we focused on the rapid spread of planting in rural areas aimed at generating high economic benefits.

Our results demonstrate that, based on current planting trends in Luxi County, Jianshui County, and Mengzi City, areas of fruit cultivation and associated profits will increase in all cases, in line with national policy on poverty alleviation and desertification control. However, this hindered the study of regional changes in ecosystem service provision caused by land-use changes. The expansion in the planting area meant that total ecosystem service provisions for Luxi County, Jianshui County, and Mengzi City were projected to increase significantly; however, accounting for the increase in the growing area, a 3\% decline is projected for Jianshui County and Mengzi City (Table 5). For example, all types of services are expected to decline in Jianshui County, while provisioning services in Mengzi City could decrease by as much as $28 \%$, contrary to expectations. Across the entire study area, TES provision will increase by $78 \%$ by 2023 , based on current development trends, indicating that complementary and diverse land-use modes can limit ongoing decline; in other words, there are tradeoffs in spatial ecosystem services [28]. In addition, fine-scale land-use management interventions can be used to maximize ecosystem service gains [29].

In our forecasts, the economic priority scenario met expectations to provide the largest increase in provisioning services while also achieving the highest overall TES. In contrast, provisioning services declined in Jianshui County and Mengzi City under the ecological priority scenario. Furthermore, provisioning services increased by $17 \%$ under the ecological priority scenario in Luxi County, where there was an overall increase of $11 \%$ in all services; this was $4 \%$ lower than in the economic priority scenario. Declines in supporting, regulating, and cultural services in Luxi County are dampened, consistent with two key conclusions in previous research. The first of these was that there are tradeoffs between provisioning services and other types of services [20,30]. The second is that a reasonable spatial arrangement of land uses can ease these tradeoffs, and that outcomes can be improved by employing sophisticated land management methods at smaller scales, depending on the context [31,32]. 
According to the ecological priority scenario, the provision of supporting services increased by $50 \%$ across the entire research area; this is consistent with current trends. Ecosystem disservices (e.g., fertilizer, water, and pesticide consumption) can also change simultaneously with adjustments in the variety of crops planted $[33,34]$. Our results indicate that irrigation costs will increase to CNY 9.13 million in 2023 and CNY 14.46 million under the economic priority scenario (Tables A9 and A10). On the contrary, the costs of irrigation, pesticides, and water consumption are $>10 \%$ lower under the ecological priority scenario than under current trends. In addition, the portion of land planted with apple trees will be greatly increased, which will assist in the preservation of soil nutrients (Table A8). This demonstrates that the current development pattern is not considered optimal. Overall, the planting trend for development in Jianshui County should be adjusted, as the compromise scenario offers an effective method of reversing the current declines in ecosystem service provision while also stimulating growth. Luxi County and Mengzi City should plan development according to the compromise scenario; however, the provision of regulation services needs to be further improved in these areas.

The inability to collect sufficient information to build accurate fruit-planting maps, due to a lack of satellite data and local-scale species-specific information, was a major limitation of our study [35,36]. It is difficult to accurately evaluate long-term trends in ecosystem service provision in the fruit planting industry, as it is highly market dependent. Many external factors (e.g., changes in varieties and international market influences) affect the provisioning services associated with fruit cultivation, whereas regulation services and supporting services (including carbon fixation and oxygen release) are comparatively stable [37]. Equally, however, the ecosystem services and disservices provided by orchards that are longstanding elements of a landscape will interact with the surrounding landscape. Our study measured this only in terms of crop water requirements and irrigation cost to reflect water consumption by orchards; however, this does not consider the water exchange with the surrounding area [38]. Therefore, improved long-term statistics are needed for specific fruit varieties to more accurately predict their benefits. In addition, fruit trees-a crucial element in alleviating poverty among fruit growers-play a non-substitutable role in leisure agriculture and will provide farmers with more benefits via their ornamental value. For example, a flowering time spanning February-May and a picking period from July-October can be created by planting pear, cherry, and pomegranate orchards in adjacent areas; this would support a six-month "golden tourist season" [39]. However, tourism values are also affected by multiple interacting factors, making the benefits of developing specific fruit-farming practices difficult to determine.

\section{Conclusions}

Changes in ecosystem service provision that are the result of land-use change have received widespread attention; however, previous research has largely focused on largescale and cross-industry changes. Using a scenario-based analysis combined with a GIS framework, we found that economic income remains the primary consideration for the promotion (or self-selection by farmers) of particular fruit trees in three counties studied in China. However, by purposefully adjusting and promoting the cultivation of specific fruits, ecosystem service provision could be improved by $10-20 \%$ overall (Tables $2-5$ ). This implies that fine-scale land-use policy, planning, and management interventions could reconcile tradeoffs in ecosystem services and support ecologically and economically coordinated development. 
Author Contributions: Conceptualization, H.Z. and Z.Z. (Zhigang Zou); methodology, K.W. and F.Z.: investigation, H.Z. and Z.Z. (Zhaoxia Zeng); writing-original draft preparation, H.Z. and Z.Z. (Zhigang Zou); writing-review and editing, H.Z. and Z.Z. (Zhigang Zou); funding acquisition, F.Z. All authors have read and agreed to the published version of the manuscript.

Funding: This research was founded by the National Key Research and Development Program [grant numbers 2016YFC0502505, 2016YFC0502400], National Natural Science Foundation of China [grant numbers 32071846], Guangxi Key Research and Development Program [grant numbers AB17129002, AB17292064], and Hechiof Distinguished Experts in China.

Institutional Review Board Statement: Not applicable.

Informed Consent Statement: Not applicable.

Data Availability Statement: All data is stored at the Institute of Subtropical Agriculture, Chinese Academy of Sciences, and is available from the corresponding author on reasonable request.

Conflicts of Interest: The authors declare no conflict of interest.

\section{Appendix A}

Table A1. Climate condition of each site.

\begin{tabular}{ccccccc}
\hline Site & AT $\left({ }^{\circ} \mathbf{C}\right)$ & RH & AAP $(\mathbf{m m})$ & AAE $(\mathbf{m m})$ & AAS $(\mathbf{h})$ & $\mathbf{0 ~ c m ~ G T ~}\left({ }^{\circ} \mathbf{C}\right)$ \\
\hline Jianshui & 19.4 & $75 \%$ & 1045.5 & $\backslash \backslash \backslash \backslash \backslash \backslash \backslash$ & 2047.9 & 19.2 \\
Luxi & 16.0 & $78 \%$ & 1028.1 & 1088.0 & 1951.1 & 22.6 \\
Mengzi & 19.0 & $76 \%$ & 848.2 & 1377.1 & 2228.3 & 22.3 \\
\hline
\end{tabular}

Note: AT, average temperature; RH, relative humidity; AAP, annual average precipitation; AAE, annual average sunshine; $0 \mathrm{~cm}$ GT, $0 \mathrm{~cm}$ ground temperature; $\backslash \backslash \backslash \backslash \backslash \backslash$, no data.

Table A2. The background of the six typical fruit modes.

\begin{tabular}{|c|c|c|c|c|c|c|}
\hline Type & Pre-Investment & Harvest Period & $\begin{array}{c}\text { Irrigation } \\
\text { (Yuan/ha/Year) }\end{array}$ & $\begin{array}{c}\text { Pesticide } \\
\text { (yuan/ha/Year) }\end{array}$ & $\begin{array}{c}\text { Fertilizer } \\
\text { (Yuan/ha/Year) }\end{array}$ & $\begin{array}{c}\text { CWR } \\
(\mathrm{mm} / \text { Year })\end{array}$ \\
\hline Marigold & Almost no & $\begin{array}{l}\text { August and } \\
\text { September }\end{array}$ & 111111 & 111111 & 1846.66 & 431.6 [40] \\
\hline Orange & $\begin{array}{l}\text { The first two years } \\
\text { require some } \\
\text { fertilizer and labor } \\
\text { input each year }\end{array}$ & $\begin{array}{l}\text { January } \\
\text { to April }\end{array}$ & 111111 & 13,500 & 18,000 & 1187 [41] \\
\hline Pear & $\begin{array}{l}\text { The first three years } \\
\text { require some } \\
\text { fertilizer and labor } \\
\text { input each year }\end{array}$ & $\begin{array}{c}\text { July } \\
\text { to November }\end{array}$ & 500 & 3333.33 & 13,800 & 657.4 [42] \\
\hline Peach & $\begin{array}{l}\text { The first three years } \\
\text { require some } \\
\text { fertilizer and labor } \\
\text { input each year }\end{array}$ & $\begin{array}{c}\text { July } \\
\text { to November }\end{array}$ & 111111 & 768.75 & 3600 & $788.6[43]$ \\
\hline Apple & $\begin{array}{l}\text { The first three years } \\
\text { require some } \\
\text { fertilizer and labor } \\
\text { input each year }\end{array}$ & $\begin{array}{c}\text { July } \\
\text { to November }\end{array}$ & 111111 & 4804 & 15,250 & $666.8[42]$ \\
\hline Pomegranate & $\begin{array}{l}\text { The first four years } \\
\text { require some input in } \\
\text { fertilizer and labor } \\
\text { each year }\end{array}$ & $\begin{array}{c}\text { July } \\
\text { to November }\end{array}$ & 250 & 12,500 & 40,083 & $867.0[44]$ \\
\hline
\end{tabular}

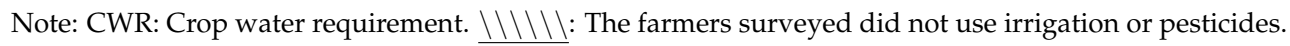


Table A3. Ecosystem services indicators and calculating method.

\begin{tabular}{|c|c|c|c|}
\hline Type & Function & Evaluation Method & Formula \\
\hline Provisioning services & Provide fruit/flowers & Market price method & $\begin{array}{c}\text { Yield of fruit/flowers }(\mathrm{kg}) \times \text { Market price } \\
(\text { yuan } / \mathrm{kg})\end{array}$ \\
\hline \multirow[t]{3}{*}{ Regulating services } & Reduce topsoil loss & Opportunity cost method & $\begin{array}{l}\text { The area of equivalent reserved land } \\
\text { (ha) } \times \text { Normal income per unit area } \\
\text { (yuan/yuan) }\end{array}$ \\
\hline & Soil fertility maintenance & Shadow price method & $\begin{array}{c}\text { The amount of nutrient loss }(\mathrm{kg}) \times \text { Market } \\
\text { price of fertilizer (yuan } / \mathrm{kg})\end{array}$ \\
\hline & photosynthetic carbon fixation & Shadow price method & $\begin{array}{l}\text { The fixed amount of carbon dioxide }(\mathrm{kg}) \\
\times \text { carbon tax (yuan) }\end{array}$ \\
\hline \multirow[t]{2}{*}{ Supporting services } & Photosynthetic oxygen release & Shadow price method & $\begin{array}{l}\text { The amount of oxygen released }\left(\mathrm{m}^{3}\right) \\
\times \text { Unit cost of industrial oxygen } \\
\text { production }\left(\text { yuan } / \mathrm{m}^{3}\right)\end{array}$ \\
\hline & Nutrient retention & Shadow price method & $\begin{array}{l}\text { Equivalent retention of } \mathrm{N}, \mathrm{P} \text { and } \mathrm{K} \text { fertilizer } \\
(\mathrm{kg}) \times \text { Market price of fertilizer (yuan } / \mathrm{kg} \text { ) }\end{array}$ \\
\hline Cultural services & Education & Replacement cost method & $\begin{array}{l}\text { Estimate the replacement cost according to } \\
\text { the equivalent education level of training }\end{array}$ \\
\hline
\end{tabular}

Note: For more details of the data computing progress, please reading our previous article [22]; And don't hesitate to contact us for more information.

Table A4. Relative ecosystem services of each pattern.

\begin{tabular}{lcccccc}
\hline & Marigold & Orange & Pear & Peach & Apple & Pomegranate \\
\hline Provisioning & 0.052 & 0.025 & 0.144 & 0.038 & 0.169 & 0.955 \\
Regulating & 0.263 & 0.701 & 0.744 & 0.990 & 0.744 & 0.572 \\
Supporting & 0.174 & 0.516 & 0.519 & 0.926 & 0.971 & 0.763 \\
Culture & 0.504 & 0.607 & 0.607 & 0.607 & 0.814 & 0.814 \\
\hline
\end{tabular}

Note: For more details of the data computing progress, please reading our previous article (Zou et al., 2020); do not hesitate to contact us for more information.

Table A5. Comprehensive land classification of Luxi county.

\begin{tabular}{|c|c|c|c|c|c|}
\hline Luxi & Soil Erosion & Slope $\left(^{\circ}\right)$ & Temperature $\left({ }^{\circ} \mathrm{C}\right)$ & Precipitation $(\mathrm{mm})$ & Area (ha) \\
\hline \multirow[t]{8}{*}{ Other farmland } & Slight & $<6$ & $15-20$ & $1000-1250$ & 9598.23 \\
\hline & & $6-15$ & $15-20$ & $1000-1250$ & 4767.75 \\
\hline & & $15-25$ & $15-20$ & $1000-1250$ & 239.58 \\
\hline & Mild & $<6$ & $15-20$ & $1000-1250$ & 2906.37 \\
\hline & & $6-15$ & $15-20$ & $1000-1250$ & 1805.04 \\
\hline & & $15-25$ & $15-20$ & $1000-1250$ & 116.01 \\
\hline & Moderate & $<6$ & $15-20$ & $1000-1250$ & 1130.4 \\
\hline & & $6-15$ & $15-20$ & $1000-1250$ & 799.29 \\
\hline \multirow[t]{6}{*}{ Bare farmland } & Slight & $<6$ & $15-20$ & $1000-1250$ & 762.75 \\
\hline & & $6-15$ & $15-20$ & $1000-1250$ & 544.14 \\
\hline & Mild & $<6$ & $15-20$ & $1000-1250$ & 728.91 \\
\hline & & $6-15$ & $15-20$ & $1000-1250$ & 504.9 \\
\hline & Moderate & $<6$ & $15-20$ & $1000-1250$ & 132.3 \\
\hline & & $6-15$ & $15-20$ & $1000-1250$ & 122.58 \\
\hline
\end{tabular}


Table A6. Comprehensive land classification of Jianshui county.

\begin{tabular}{|c|c|c|c|c|c|}
\hline Jianshui & Soil Erosion & Slop $\left(^{\circ}\right)$ & Temperature $\left({ }^{\circ} \mathrm{C}\right)$ & Precipitation $(\mathrm{mm})$ & Area (ha) \\
\hline \multirow[t]{22}{*}{ Other farmland } & slight & $<6$ & $<15$ & $750-1000$ & 95.85 \\
\hline & & & $15-20$ & $750-1000$ & $10,837.98$ \\
\hline & & & & $1000-1250$ & 374.4 \\
\hline & & $6-15$ & $<15$ & 750-1000 & 99.63 \\
\hline & & & $15-20$ & $750-1000$ & 2210.13 \\
\hline & & & & $1000-1250$ & 346.95 \\
\hline & & $15-25$ & $15-20$ & $750-1000$ & 194.49 \\
\hline & & & & $1000-1250$ & 155.79 \\
\hline & & $>25$ & $15-20$ & $1000-1250$ & 94.23 \\
\hline & Mild & $<6$ & $15-20$ & 750-1000 & 1941.39 \\
\hline & & & & $1000-1250$ & 487.89 \\
\hline & & $6-15$ & $15-20$ & $750-1000$ & 1039.23 \\
\hline & & & & $1000-1250$ & 466.65 \\
\hline & & $15-25$ & $15-20$ & 750-1000 & 97.38 \\
\hline & & & & $1000-1250$ & 142.11 \\
\hline & Moderate & $<6$ & $15-20$ & 750-1000 & 942.84 \\
\hline & & & & $1000-1250$ & 179.55 \\
\hline & & $6-15$ & $15-20$ & $750-1000$ & 651.24 \\
\hline & & & & $1000-1250$ & 127.8 \\
\hline & & $15-25$ & $15-20$ & 750-1000 & 175.68 \\
\hline & Intensity & $<6$ & $15-20$ & $750-1000$ & 463.95 \\
\hline & & $6-15$ & $15-20$ & 750-1000 & 227.52 \\
\hline \multirow[t]{15}{*}{ Bare farmland } & Slight & $<6$ & $15-20$ & 750-1000 & 974.97 \\
\hline & & & & $1000-1250$ & 268.74 \\
\hline & & $6-15$ & $15-20$ & 750-1000 & 352.35 \\
\hline & & & & $1000-1250$ & 295.11 \\
\hline & & $15-25$ & $15-20$ & $1000-1250$ & 135.09 \\
\hline & Mild & $<6$ & $15-20$ & 750-1000 & 836.37 \\
\hline & & & & $1000-1250$ & 683.91 \\
\hline & & $6-15$ & $15-20$ & 750-1000 & 481.32 \\
\hline & & & & $1000-1250$ & 688.86 \\
\hline & & $15-25$ & $15-20$ & $1000-1250$ & 162.54 \\
\hline & Moderate & $<6$ & $15-20$ & 750-1000 & 480.78 \\
\hline & & & & $1000-1250$ & 295.11 \\
\hline & & $6-15$ & $15-20$ & 750-1000 & 290.88 \\
\hline & & & & $1000-1250$ & 274.86 \\
\hline & Intensity & $<6$ & $15-20$ & 750-1000 & 186.66 \\
\hline
\end{tabular}

Table A7. Comprehensive land classification of Mengzi city.

\begin{tabular}{|c|c|c|c|c|c|}
\hline Mengzi & Soil Erosion & Slop $\left(^{\circ}\right)$ & Temperature $\left({ }^{\circ} \mathrm{C}\right)$ & Precipitation $(\mathrm{mm})$ & Area (ha) \\
\hline \multirow[t]{9}{*}{ Other farmland } & Micro & $<6$ & $15-20$ & $750-1000$ & 1602.63 \\
\hline & & & & $1000-1250$ & 7424.19 \\
\hline & & $6-15$ & $15-20$ & 750-1000 & 199.71 \\
\hline & & & & $1000-1250$ & 1145.61 \\
\hline & & $15-25$ & $15-20$ & $1000-1250$ & 146.52 \\
\hline & Mild & $<6$ & $15-20$ & $1000-1250$ & 402.66 \\
\hline & & $6-15$ & $15-20$ & $1000-1250$ & 391.05 \\
\hline & Moderate & $<6$ & $15-20$ & $1000-1250$ & 200.79 \\
\hline & & $6-15$ & $15-20$ & $1000-1250$ & 192.60 \\
\hline \multirow[t]{6}{*}{ Bare farmland } & Micro & $<6$ & $15-20$ & 750-1000 & 465.12 \\
\hline & & & & $1000-1250$ & 2144.88 \\
\hline & & $6-15$ & $15-20$ & $1000-1250$ & 502.11 \\
\hline & Mild & $<6$ & $15-20$ & $1000-1250$ & 295.65 \\
\hline & & $6-15$ & $15-20$ & $1000-1250$ & 236.88 \\
\hline & Moderate & $<6$ & $15-20$ & $1000-1250$ & 95.94 \\
\hline
\end{tabular}


Table A8. Soil characteristics of six typical fruit modes.

\begin{tabular}{cccccccc}
\hline Type & AP $(\mathbf{m g} / \mathbf{k g})$ & TP $(\mathbf{g} / \mathbf{k g})$ & AN $(\mathbf{m g} / \mathbf{k g})$ & TN $(\mathbf{g} / \mathbf{k g})$ & AK $(\mathbf{m g} / \mathbf{k g})$ & TK $(\mathbf{g} / \mathbf{k g})$ & OM $(\mathbf{g} / \mathbf{k g})$ \\
\hline Marigold & $28.49 \pm 10.60$ & $0.82 \pm 0.10$ & $215.73 \pm 47.01$ & $1.67 \pm 0.35$ & $36.15 \pm 14.19$ & $0.20 \pm 0.17$ & $28.22 \pm 4.291$ \\
Orange & $36.76 \pm 6.09$ & $0.64 \pm 0.03$ & $140 \pm 17.72$ & $1.44 \pm 0.28$ & $35.1 \pm 1.66$ & $2.53 \pm 0.47$ & $27.12 \pm 3.19$ \\
Peach & $43.49 \pm 10.575$ & $1.06 \pm 0.07$ & $108.96 \pm 25.00$ & $1.21 \pm 0.22$ & $62.85 \pm 11.39$ & $8.97 \pm 0.77$ & $24.09 \pm 4.75$ \\
Pear & $158.11 \pm 68.59$ & $0.98 \pm 0.17$ & $132.08 \pm 43.80$ & $0.94 \pm 0.11$ & $27.64 \pm 9.99$ & $3.95 \pm 0.10$ & $16.37 \pm 3.14$ \\
Apple & $143.55 \pm 71.72$ & $1.87 \pm 0.45$ & $203.4 \pm 15.06$ & $2.23 \pm 0.48$ & $58.03 \pm 1.41$ & $7.95 \pm 1.88$ & $33.49 \pm 2.98$ \\
Pomegranate & $43.65 \pm 26.64$ & $0.37 \pm 0.13$ & $614.15 \pm 68.76$ & $1.31 \pm 0.18$ & $65.51 \pm 11.32$ & $0.47 \pm 0.20$ & $12.09 \pm 1.52$ \\
\hline
\end{tabular}

Note: AP, available phosphorus; TP, total phosphorus; AN, Available nitrogen; TN, Total nitrogen; AK, Available potassium; TK, Total potassium; OM, Organic Matter.

Table A9. Irrigation, pesticide, fertilizer, and water consumption of the total research area under different scenarios.

\begin{tabular}{ccccc}
\hline & $\begin{array}{c}\text { Irrigation } \\
\text { (Million Yuan) }\end{array}$ & $\begin{array}{c}\text { Pesticide } \\
\text { (Million Yuan) }\end{array}$ & $\begin{array}{c}\text { Total } \\
\text { Fertilizer } \\
\text { (Million Yuan) }\end{array}$ & $\begin{array}{c}\text { Water } \\
\text { (Million m }{ }^{\mathbf{3}} \text { ) }\end{array}$ \\
\hline 2016 & 6.63 & 195.61 & 569.15 & 256.48 \\
2017 & 6.81 & 206.20 & 594.55 & 272.96 \\
2018 & 7.22 & 230.47 & 642.59 & 293.41 \\
2023 & 9.13 & 415.00 & 1041.96 & 549.62 \\
Economic priority & 14.46 & 595.06 & 1809.22 & 540.95 \\
Compromise & 12.58 & 537.42 & 1623.25 & 525.96 \\
Ecological priority & 7.16 & 370.33 & 1084.07 & 482.49 \\
\hline
\end{tabular}

Note: Water, annual water consumption calculated from the theoretical water requirement of each crop.

Table A10. Irrigation, pesticide, fertilizer, and water consumption under different scenarios of each city (county).

\begin{tabular}{|c|c|c|c|c|c|c|c|c|c|c|c|c|}
\hline & \multicolumn{4}{|c|}{ Luxi } & \multicolumn{4}{|c|}{ Jianshui } & \multicolumn{4}{|c|}{ Mengzi } \\
\hline & Irrigation & Pesticide & Fertilizer & Water & Irrigation & Pesticide & Fertilizer & Water & Irrigation & Pesticide & Fertilizer & Water \\
\hline 2016 & 4.43 & 37.50 & 154.06 & 99.69 & 0.65 & 65.13 & 122.21 & 60.93 & 1.55 & 92.98 & 292.89 & 95.86 \\
\hline 2017 & 4.60 & 40.26 & 163.45 & 104.26 & 0.70 & 73.00 & 138.25 & 67.09 & 1.52 & 92.94 & 292.84 & 101.61 \\
\hline 2018 & 4.80 & 43.35 & 174.62 & 111.17 & 0.68 & 85.65 & 154.70 & 78.33 & 1.75 & 101.47 & 313.27 & 103.91 \\
\hline 2023 & 5.85 & 68.63 & 263.46 & 164.09 & 0.84 & 176.34 & 295.52 & 155.90 & 2.44 & 170.03 & 482.98 & 229.63 \\
\hline $\begin{array}{l}\text { Economic } \\
\text { priority }\end{array}$ & 6.76 & 141.53 & 488.57 & 177.20 & 2.33 & 171.04 & 428.10 & 137.00 & 5.37 & 282.48 & 892.55 & 226.75 \\
\hline Compromise & 6.19 & 123.83 & 431.44 & 172.59 & 1.16 & 134.88 & 311.41 & 127.60 & 5.24 & 278.72 & 880.40 & 225.77 \\
\hline $\begin{array}{c}\text { Ecological } \\
\text { priority }\end{array}$ & 4.80 & 81.09 & 293.52 & 161.47 & 0.61 & 118.20 & 257.61 & 123.26 & 1.75 & 171.04 & 532.94 & 197.76 \\
\hline
\end{tabular}

Note: The unit for "Irrigation", "Pesticide" and, "Fertilizer" is "CHY Million". The unit for "Water" is "Million m".

\section{References}

1. Yao, L.S. The formation mechanism and model of faulted karst basins in Yunan province. Carsologica Sin. 1984, 2, 48. (In Chinese)

2. Wang, S.J.; Zhang, X.B.; Bai, X.Y. Discussion on nomenclature of the karst desertification regions and illustration for their environment characteristics in southwest China. J. Mt. Sci. 2013, 31, 18-24. (In Chinese) [CrossRef]

3. Wang, Y.; Zhang, G. The Rocky Desertification of Karst Tableland and Countermeasures in East of Yunan. In Study on Karst Groundwater and Rocky Desertification in China; Guangxi Science and Technology Press: Nanning, China, 2003.

4. Liu, B.; Xie, Y.; Li, Z.; Liang, Y.; Zhang, W.; Fu, S.; Yin, S.; Wei, X.; Zhang, K.; Wang, Z.; et al. The assessment of soil loss by water erosion in China. Int. Soil Water Conserv. Res. 2020, 8, 430-439. [CrossRef]

5. Cao, S.S.; Wang, Y.H.; Duan, F.Z.; Zhao, W.J.; Wang, Z.H.; Fang, N. Coupling between ecological vulnerability and economic poverty in contiguous destitute areas, China: Empirical analysis of 714 poverty-stricken counties. Chin. J. Appl. Ecol. 2016, 27, 2614-2622. [CrossRef]

6. Wang, Y.; Zhang, G. On the desertification and genesis of karst stone mountain area in east Yunnan. Adv. Earth Sci. 2003, 18, 933-938. (In Chinese)

7. Cheng, H.D.; Yin, X.F. Study on innovation of precise poverty alleviation model in agricultural universities. J. Huazhong Agric. Univ. 2018, 2, 72-78. (In Chinese) [CrossRef]

8. Lan, H.Q.; Deng, X.X. Industrial Poverty Alleviation Mode Supported by research Team of Pomology Discipline-Based on the Cases by Citrus Team of Huazhong Agricultural University. J. Agric. Sci. Technol. 2019, 21, 1-7. (In Chinese)

9. Wu, J.Q.; He, H.Y.; Su, N.; Deng, R.L. The spatial pattern of fruit industry and its logistics network design in Yunnan province. Econ. Geogr. 2019, 39, 135-142. (In Chinese) [CrossRef] 
10. Rocky Desertification Bulletin 2016; National Forestry and Grassland Administration of China: Beijing, China, 2016.

11. Wu, T.; Wang, Y.; Yu, C.J.; Chiarawipa, R.; Zhang, X.Z.; Han, Z.H.; Wu, L.H. Carbon Sequestration by Fruit Trees-Chinese Apple Orchards as an Example. PLoS ONE 2012, 7, e38883. [CrossRef]

12. Deng, L.; Shangguan, Z.P. Afforestation Drives Soil Carbon and Nitrogen Changes in China. Land Degrad. Dev. 2016, 28, 151-165. [CrossRef]

13. Lang, Y.Q.; Song, W.; Deng, X.Z. Projected land use changes impacts on water yields in the karst mountain areas of China. Phys. Chem. Earth 2017, 104, 66-75. [CrossRef]

14. Baumgartner, J.; Bieri, M. Fruit tree ecosystem service provision and enhancement. Ecol. Eng. 2006, 27, 118-123. [CrossRef]

15. Sherrouse, B.C.; Semmens, D.J.; Ancona, Z.H.; Brunner, N.M. Analyzing land-use change scenarios for trade-offs among cultural ecosystem services in the Southern Rocky Mountains. Ecosyst. Serv. 2017, 26, 431-444. [CrossRef]

16. Pang, D.; Wang, G.; Li, G.; Sun, Y.; Liu, Y.; Zhou, J. Ecological Stoichiometric Characteristics of Two Typical Plantations in the Karst Ecosystem of Southwestern China. Forests 2018, 9, 56. [CrossRef]

17. Lu, H.F.; Cai, C.J.; Zeng, X.S.; Campbell, D.E.; Fan, S.H.; Liu, G.L. Bamboo vs. crops: An integrated emergy and economic evaluation of using bamboo to replace crops in south Sichuan Province, China. J. Clean. Prod. 2018, 177, 464-473. [CrossRef] [PubMed]

18. Zou, Z.G.; Zeng, F.P.; Wang, K.L.; Zeng, Z.X.; Zhao, L.L.; Du, H.; Zhang, F.; Zhang, H. Emergy and Economic Evaluation of Seven Typical Agroforestry Planting Patterns in the Karst Region of Southwest China. Forests 2019, 10, 138. [CrossRef]

19. Zhao, L.L.; Chen, J.S.; Cheng, Y.F.; Zhu, S.R.; Zhou, H.J.; Tang, F.L.; Lan, F.L. Analysis on the characteristics and influencing factors of rocky desertification evolution in Honghe Prefecture, Yunnan province. Soil Water Con. Chin. 2019, 7, 40-44. (In Chinese) [CrossRef]

20. Zou, Z.G.; Zeng, F.P.; Wang, K.L.; Zeng, Z.X.; Tang, H.; Zhang, H. Evaluation and Tradeoff Analysis of Ecosystem Service for Typical Land-Use Patterns in the Karst Region of Southwest China. Forests 2020, 11, 451. [CrossRef]

21. Li, C.C.; Gong, P.; Wang, J.; Zhu, Z.L.; Biging, G.S.; Yuan, C.; Hu, T.Y.; Zhang, H.Y.; Wang, Q.; Li, X.C.; et al. The first all-season sample set for mapping global land cover with Landsat-8 data. Sci. Bull. 2017, 62, 508-515. [CrossRef]

22. Xu, S.T.; He, X.; Yang, P.W.; Bai, T.T.; Fan, H.C.; Yin, K.S.; Yang, B.M.; Zheng, S.J. Effect of climatic factors on the banana growth and its fruit quality at different altitudes. J. Yunnan Agric. Univ. (Nat. Sci.) 2020, 35, 102-107. (In Chinese)

23. Goldstein, J.H.; Caldarone, G.; Duarte, T.K.; Ennaanay, D.; Hannahs, N.; Mendoza, G.; Polasky, S.; Wolny, S.; Daily, G.C. Integrating ecosystem-service tradeoffs into land-use decisions. Proc. Natl. Acad. Sci. USA 2012, 109, 7565-7570. [CrossRef] [PubMed]

24. Yu, X.X.; Yang, G.S. The Advances and Problems of Land Use and Land Cover Change Research in China. Prog. Geogr. 2002, 1, 51-57. (In Chinese)

25. Chen, H.; Shi, Y.Y.; Ke, X.L.; Hao, J.M.; Chen, A.Q. Spatial optimization of land use based on the objective of coordinated ecological protection and economic development in Zhengzhou City. Resour. Sci. 2019, 41, 717-728, (In Chinese, with English abstract). [CrossRef]

26. Zhou, C.Y.; Chen, X.; Liu, X.L.; Zhao, W.Q.; Li, K.; Tang, J.G. Assessment of Karst Regional Ecosystem Service Functions Based on Land Use Change: A Case Study in Guizhou, China. Chin. J. Appl. Environ. Biol. 2011, 17, 174-179. [CrossRef]

27. Padilla, F.M.; Vidal, B.; Sanchez, J.; Pugnaire, F.I. Land-use changes and carbon sequestration through the twentieth century in a Mediterranean mountain ecosystem: Implications for land management. J. Environ. Manag. 2010, 91, 2688-2695. [CrossRef] [PubMed]

28. Jia, X.Q.; Fu, B.J.; Feng, X.M.; Hou, G.H.; Liu, Y.; Wang, X.F. The tradeoff and synergy between ecosystem services in the Grain-for-Green areas in Northern Shaanxi, China. Ecol. Indic. 2014, 43, 103-113. [CrossRef]

29. Grafius, D.R.; Corstanje, R.; Warren, P.H.; Evans, K.L.; Hancock, S.; Harris, J.A. The impact of land use/land cover scale on modelling urban ecosystem services. Landsc. Ecol. 2016, 31, 1509-1522. [CrossRef]

30. Kibria, A.; Costanza, R.; Groves, C.; Behie, A.M. The interactions between livelihood capitals and access of local communities to the forest provisioning services of the Sundarbans Mangrove Forest, Bangladesh. Ecosyst. Serv. 2018, 32, 41-49. [CrossRef]

31. Law, E.A.; Bryan, B.A.; Meijaard, E.; Mallawaarachchi, T.; Struebig, M.; Wilson, K.A. Ecosystem services from a degraded peatland of Central Kalimantan: Implications for policy, planning, and management. Ecol. Appl. 2015, 25, 70-87. [CrossRef]

32. Raudsepp-Hearne, C.; Peterson, G.D.; Bennett, E.M. Ecosystem service bundles for analyzing tradeoffs in diverse landscapes. Proc. Natl. Acad. Sci. USA 2010, 107, 5242-5247. [CrossRef]

33. Demestihas, C.; Plenet, D.; Genard, M.; Raynal, C.; Lescourret, F. A simulation study of synergies and tradeoffs between multiple ecosystem services in apple orchards. J. Environ. Manag. 2019, 236, 1-16. [CrossRef]

34. Herd-Hoare, S.; Shackleton, C. Ecosystem disservices matter when valuing ecosystem benefits from small-scale arable agriculture. Ecosyst. Serv. 2020, 46, 101201. [CrossRef]

35. Nguyen, K.A.; Liou, Y.A. Global mapping of eco-environmental vulnerability from human and nature disturbances. Sci. Total Environ. 2019, 664, 995-1004. [CrossRef]

36. Peng, D.; Wang, Y.; Xian, G.; Huete, A.R.; Huang, W.; Shen, M.; Wang, F.; Yu, L.; Liu, L.; Xie, Q.; et al. Investigation of land surface phenology detections in shrublands using multiple scale satellite data. Remote Sens. Environ. 2021, 252. [CrossRef]

37. Zhang, M.; Wang, K.; Liu, H.; Zhang, C. Responses of spatial-temporal variation of Karst ecosystem service values to landscape pattern in northwest of Guangxi, China. Chin. Geogr. Sci. 2011, 21, 446-453. [CrossRef] 
38. SchÄCkermann, J.; Pufal, G.; Mandelik, Y.; Klein, A.-M. Agro-ecosystem services and dis-services in almond orchards are differentially influenced by the surrounding landscape. Ecol. Entomol. 2015, 40, 12-21. [CrossRef]

39. Wei, L.; Zhou, J.; Yan, Z.; Chen, L.; Liu, H. Function of fruit trees in leisure agriculture Jiangsu. J. Agric. Sci. 2018, 34, 657-666. (In Chinese) [CrossRef]

40. Fan, J.; Liu, Y.; Zhu, F. Study on growth habit and high quality and high yield cultivation technique of Chrysanthemum medicinalis in coastal beach of north Jiangsu province. Shanghai Agric. Sci. Technol. 2001, 6, 91-92. (In Chinese)

41. Tan, H.; Zhou, L.; Tan, J.; Yang, S.; Lv, K.; Huang, J. Technologies of water and fertilizer management for high-quality and high-yield citrus in Guangxi. J. South. Agric. 2019, 6, 1290-1296. (In Chinese) [CrossRef]

42. Zhang, S.; Xu, S.; Jia, Y.; Guo, X. Peach water consumption laws by drip irrigation in greenhouse. South-to-North Water Transf. Water Sci. Technol. 2005, 2, 38-40. (In Chinese) [CrossRef]

43. Guo, D.; Qian, C.; Cheng, F. Comparative study on water requirement characteristics of different crops. Water Sav. Irrig. 2013, 6, 67-69. (In Chinese)

44. Fang, Y. Water requirement test and preliminary draft of irrigation system for pomegranate. Water Sav. Irrig. 2001, 3, 16-17. (In Chinese) 